\title{
CAREERS
}

NATUREJOBS BLOG Expert careers advice, updates and discussions go.nature.com/28g4a7
@NATUREJOBS Follow us on Twitter for the latest news and features go.nature.com/e492gf
NATUREJOBS For the latest career

listings and advice www.naturejobs.com

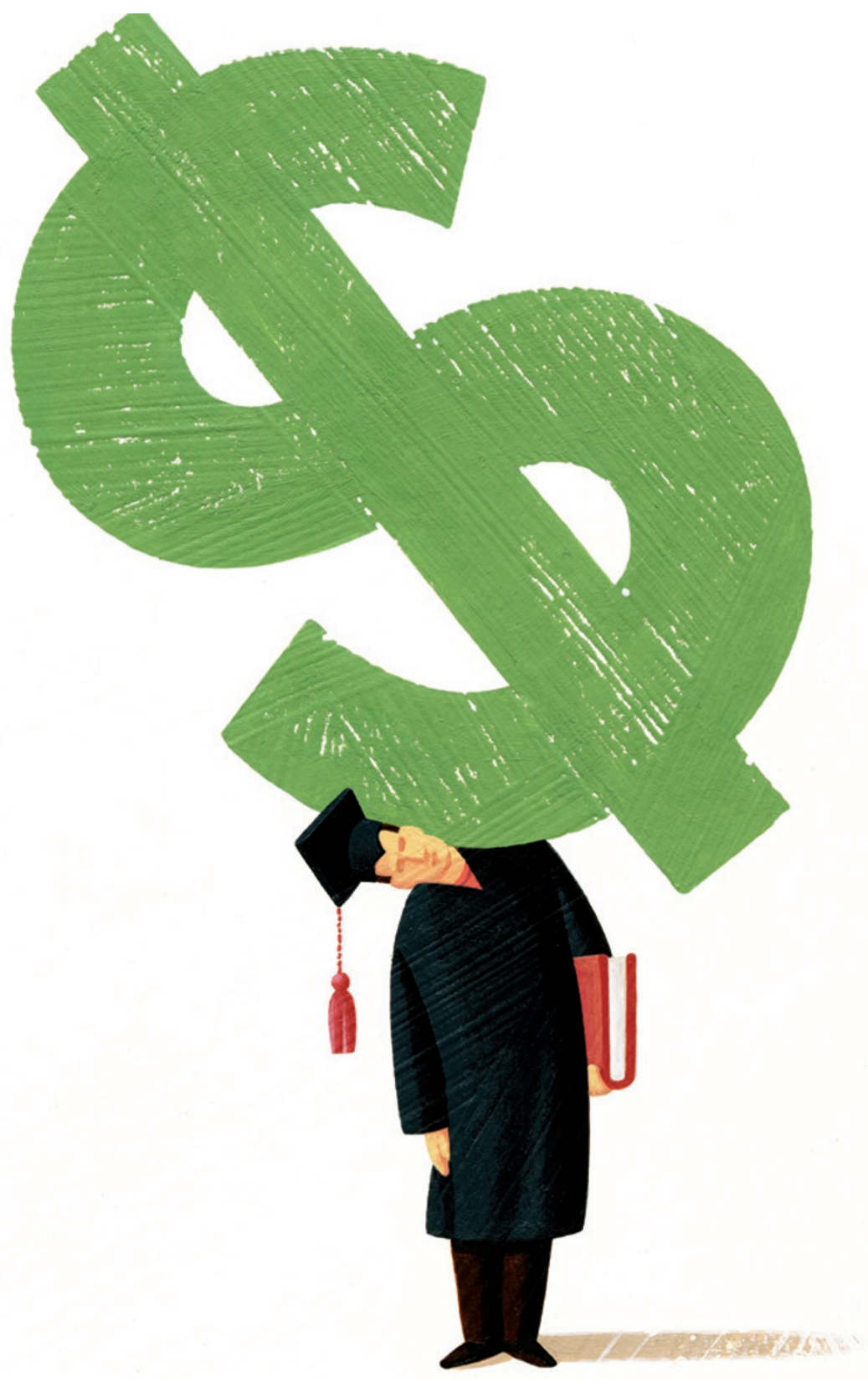

EDUCATION
Graduate students face big decisions about money. They can benefit from wise counsel and careful forethought.
BY GENE RUSSO

$A$ fter finishing her $\mathrm{PhD}$ in April, Kristina Stemler came to a crossroads. Should she pursue the tantalizing dream of pure research in academia, or find an industry job in which product sales govern priorities and shape career prospects? Her decision depended on many considerations - what did she enjoy most? What was most satisfying? Where would the hottest jobs be? And then there was that other matter looming in the back of her mind and sometimes keeping her up at night: the fact that she is tens of thousands of dollars in debt.

Stemler is one of many junior researchers who face huge debt on top of the alreadydaunting burdens of getting funding, landing a position and toiling for long hours in the lab. Debt can cause stress and change the calculus of career decisions. It does not usually accumulate as a result of graduate studies - for which students often get fellowships or other funding - but from the ever-increasing cost of an undergraduate education. In the United States, tuition fees have increased faster than inflation, and total student debt now exceeds the nation's credit-card debt.

Managing the bills is an ever-growing challenge. But even if early-career scientists have the resources to avoid amassing huge debt, they still have to face fiscal realities. Graduate students must learn to get by on sometimes meagre stipends while still planning ahead for big costs - buying a home, setting aside a rainy-day fund or squirrelling away cash for retirement. In a tight funding climate and tough academic job market, they are discovering the importance of financial planning.

\section{DEBT COLLECTION}

Gauging the scope of the debt problem for graduate students is difficult, but the 2013 Nature Careers Graduate Student Survey included questions intended to measure money anxiety (for further results, see 'Graduate trends'). Of more than 5,000 graduate students who responded by e-mail, on websites and through social media, $39 \%$ were 'concerned' or 'very concerned' about debt. (Even more may have been so concerned about debt that they left higher education, but the survey reached only current students). According to the US National Science Foundation, life scientists who earned a PhD in the United States in 2011 held an average debt of US\$17,426; physical scientists had an average of $\$ 12,146$.

For graduate students around the world, 
$\checkmark$ debt can be a career game-changer (see 'Money woes in China'). Dismayed by her financial burden and the bleak job prospects in academia, Stemler is planning to move into translational medicine and then, she hopes, into cancer-diagnostics research at a biotechnology or pharmaceutical company. To help with that, she is about to embark on a postdoc at the University of Texas MD Anderson Cancer Center in Houston, where she wants to focus on the mitigation of chemotherapy symptoms and how cells respond to treatment. "I was already disillusioned with the situation now in academia," she tells Nature while on a break from driving from her graduate

"In a tight
funding climate
and tough
academicjob
market, students
are discovering
the importance
of financial
planning."
school, Washington University in St. Louis, Missouri, to Houston. "And then I had financial worries - and there was the sequester" (see Nature 498, 527-528; 2013).

But some students, such as survey respondent Aditi Dubey, are still intent on pursuing academia. Dubey, who is undertaking a molecular-biology PhD at Rutgers University in New Brunswick, New Jersey, was fortunate in that her parents helped her to pay for her undergraduate degree at Drexel University in Philadelphia, Pennsylvania. She also took a part-time job. Now in the fifth year of her $\mathrm{PhD}$, she is relatively debt-free; her annual $\$ 28,000$ stipend has been sufficient, although she does have to miss the occasional conference if her principal investigator does not have the funding. But Dubey is cognizant of her financial constraints, and she covets the

milestone acquisitions of many young professionals: a car, a house.

Dubey plans to do a postdoc in neuroscience, and to stay in academia unless she fails to secure a professorship after a sustained, concerted effort. She revels in the freedom, pace and culture of academic research - benefits that she found lacking on a research placement at pharmaceutical company Merck in West Point, Pennsylvania, during her undergraduate studies. Industry is Dubey's plan B; her plan C is to become a consultant on life-sciences research. "Finances could be why I give up on the academic track," she says.

Michael Sunde, who studies geographic information systems (GIS) at the University of Missouri in Columbia, has similar financial concerns. His skills put him in demand in the private sector, but he remains keen on academia, aiming for a post in which he can apply GIS to urban-growth issues such as modelling and tracking rainwater runoff. Private-sector opportunities are more plentiful and, in many cases, better paid - he has several classmates who have been recruited by defence contractors interested in monitoring objects of interest, not weather. But academia remains Sunde's ideal despite his debt of about $\$ 50,000$. “There’s so much anxiety that I can't think about it," he says. "I have to push it aside."

\section{FINANCIAL MANAGEMENT}

The US Council of Graduate Schools (CGS) in Washington DC, an association of US universities, has taken notice of such cases. Last November, the CGS and TIAA-CREF, a financial-services provider based in New York City, launched the first phase of a three-year programme to improve the debt-management and financial-planning abilities of graduate and

\section{GLOBAL OUTLOOK Money woes in China}

Researchers in China face some of the most acute debt worries, according to the 2013 Nature Careers Graduate Student Survey. In China, $67 \%$ of respondents were 'concerned' or 'very concerned' about their debt. Of the other countries with sizeable respondent samples, the Netherlands had the fewest expressing concern, at $17 \%$; the United Kingdom was next lowest at 20\%. In the United States, $26 \%$ of respondents were concerned or very concerned.

For many students in China, and Asia in general, such worries are attributable to rising education costs and tough job markets, says Denis Simon, an expert on China and viceprovost for international strategic initiatives at Arizona State University in Tempe. Increasingly, he notes, Chinese students who come to the United States for what they hope will be a superior education are not just the wealthy, but also from the middle class. Their families struggle to pay the US $\$ 40,000$ per year or more for a full undergraduate education - much more than in China. There is little financial assistance available for foreign students in the United States, and it is hard for them to get jobs off campus for more than 10-15 hours a week. Those who go on to graduate studies hold large debt — and many graduates, says Simon, have difficulty finding well-paid jobs. The costs of living in Beijing or Shanghai are challenging, whether one has studied abroad or not.

"The concern about having to be successful upon graduation runs deep," says Simon, "especially for Chinese, who may borrow from within their families and relatives." G.R. undergraduate students. So far, 15 institutions have been selected to participate; each received grants to develop financial-literacy projects, assess students' needs and augment financialplanning resources and tools. Another 19 affiliate university partners will be invited to share education tools and promising practices, and to take part in the programme's study of graduate students' financial habits.

The impetus for the project involved a number of factors, says Daniel Denecke, a CGS associate vice-president who is heading the effort. "It was the rising amount of student debt we were seeing nationally: how hardship and issues are increasingly playing a role in student decisions to defer plans to go into grad school." Programme leaders noted that student borrowing is not necessarily informed by longer-term salary potential, and wanted to help students "to make informed decisions when they do borrow", says Denecke, "by having access to projections on how the amount they borrow will affect their career decisions".

The Ohio State University (OSU) in Columbus is among the programme's grantees. The university's graduate school and its Student Wellness Center are planning online tutorials that will offer guidance on such tasks as compiling a monthly budget or assessing the riskiness of financial practices. They will send out financial surveys, and counsellors will use the responses to reach out to students who seem to be at high risk of getting into difficulties. Part of the OSU's strategy is to tailor its advice to key phases in student life - the admissions process, candidacy after completing initial course requirements and graduation, says graduateschool dean Patrick Osmer. For example, newly admitted students probably do not need information about retirement, but they should have insight into the salary prospects in a given field.

Osmer also supports training graduate students to be peer counsellors, reasoning that students respond better when they hear something from their peers rather than from an administrator or instructor.

\section{CLEAN CREDIT}

Cornell University in Ithaca, New York another CGS grant recipient - is planning to pool the resources of multiple campus offices to educate students about debt and financial management both in person and online. The university already works with ClearPoint, a financial-advice non-profit based in Richmond, Virginia, which conducts workshops and telephone consultations focused on budgeting, financial management and handling debt.

The workshops have been very well attended, says Gary Thurber, who was until recently a ClearPoint credit counsellor and educator. He had expected students to be most interested in budgeting and goal-setting - working out, for example, how to make a stipend instalment received in August last until January. But what most students want to know about, he says, 


\section{Graduate trends}

The 2013 Nature Careers Graduate Student Survey collected more than 5,000 responses from graduate students around the world. The questions, like those of the inaugural 2011 survey, probed concerns about funding, working conditions and the factors affecting careers paths; this year's survey also asked about student debt.

Q To what extent are you satisfied with each of the following attributes or aspects of your graduate-school experience?

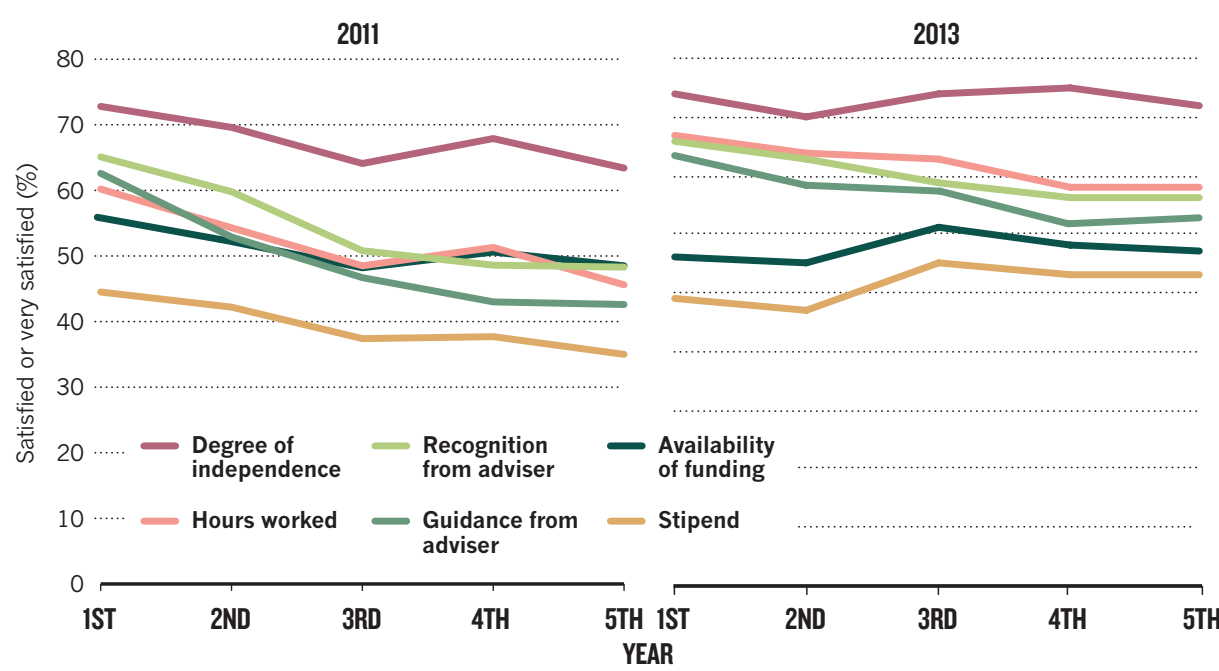

Q How concerned, if at all, are you about any debt you will incur from pursuing your post-graduate qualification or degree?

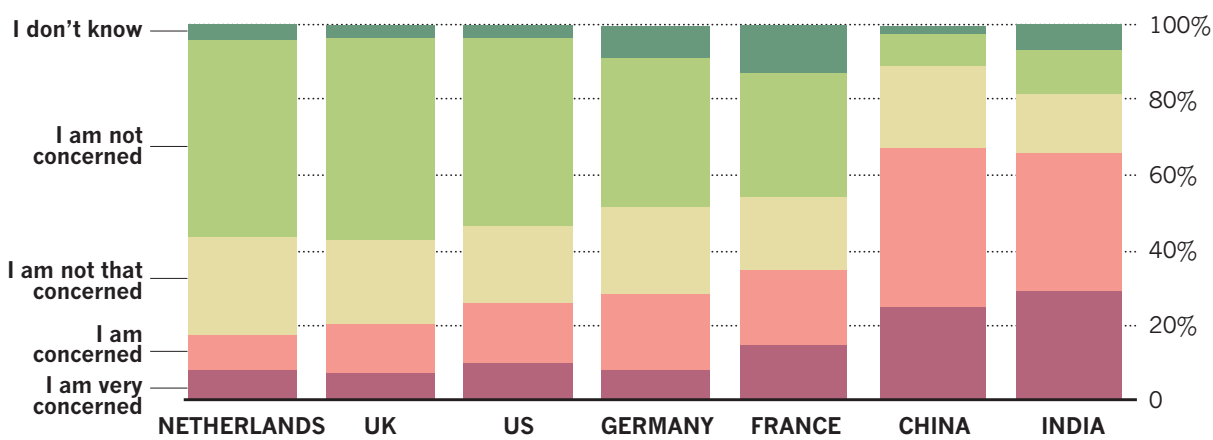

Q Which, if any, of the following are reasons that you feel less likely to follow a traditional research career than you did when you started your $\mathrm{PhD}$ ?

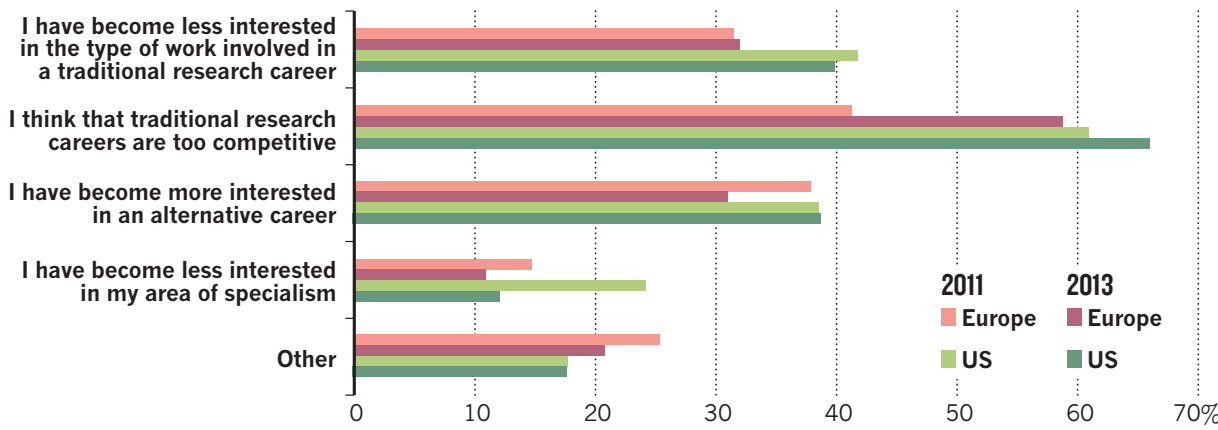

are credit reports and the best ways to obtain mortgages. He tells them how to get free credit reports (avoid the unnecessary charges of the oft-advertised freecreditreport.com, and opt instead for the federally authorized www. annualcreditreport.com, which delivers one free report per year from each of the three US credit-reporting agencies). He also advises students to keep their credit-card balances below $40 \%$ of the credit limit, and to be wary of transferring balances between cards.

Still, Thurber does discuss debt, advising students to borrow only what they need. Even with low interest rates, payments add up, he notes. He often counsels students to get a parttime job to cover basic expenses.
Q Overall, how satisfied are you with your graduate-school experience? By region.*
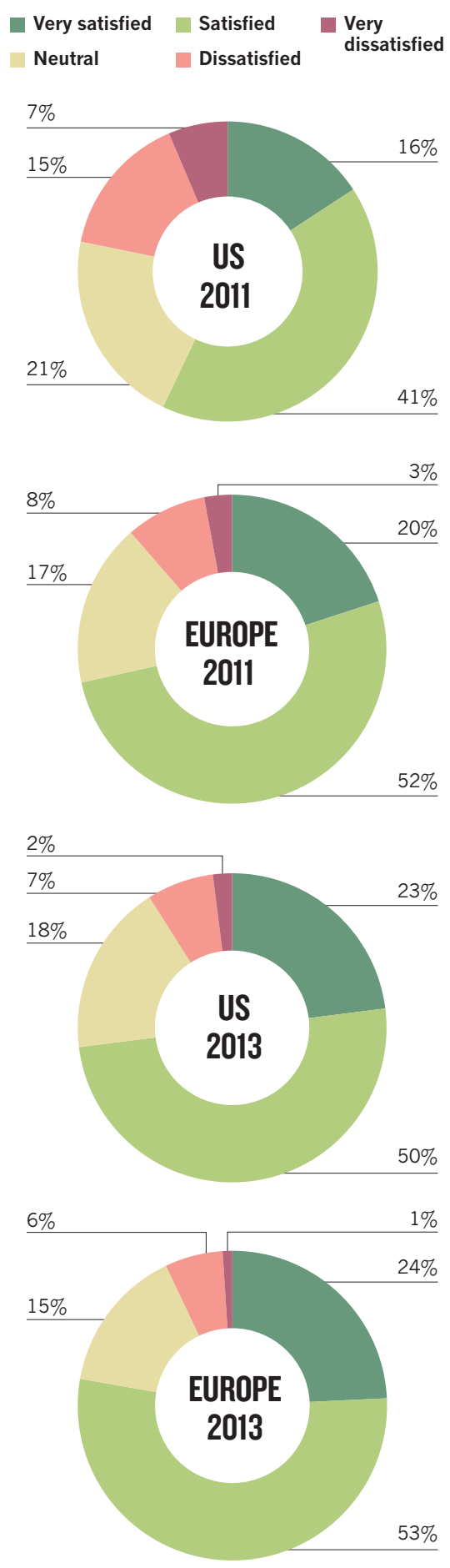

*Owing to rounding, numbers may not add up to $100 \%$

"In our colleges and schools," says Thurber, "we do a great job of educating our people for jobs they're trained to do. But I don't think right now that many colleges are teaching students about personal finance. We're not teaching them what to do with income once they have it."

Gene Russo is Careers editor at Nature. 